\title{
Inhibition of $\alpha$-class cytosolic human carbonic anhydrases I, II, IX and XII, and $\beta$-class fungal enzymes by carboxylic acids and their derivatives: New isoform-I selective nanomolar inhibitors
}

\author{
Mario Sechi ${ }^{\mathrm{a}, *}$, Alessio Innocenti $^{\mathrm{b}}$, Nicolino Pala ${ }^{\mathrm{a}}$, Dominga Rogolino ${ }^{\mathrm{c}}$, Mauro Carcelli ${ }^{\mathrm{c}}$, \\ Andrea Scozzafava ${ }^{\mathrm{b}}$, Claudiu T. Supuran ${ }^{\mathrm{b}, *}$ \\ ${ }^{a}$ Dipartimento di Chimica e Farmacia, Università di Sassari, Via Muroni 23/A, 07100 Sassari, Italy \\ ${ }^{\mathrm{b}}$ Dipartimento di Chimica, Laboratorio di Chimica Bioinorganica, Università degli Studi di Firenze, Rm 188, Via della Lastruccia 3, Polo Scientifico, I 50019 Sesto Fiorentino \\ (Firenze), Italy \\ ${ }^{\mathrm{c}}$ Dipartimento di Chimica, Università di Parma, Parco Area delle Scienze 17/A, 43124 Parma, Italy
}

\section{A R T I C L E I N F O}

\section{Article history:}

Received 25 June 2012

Revised 23 July 2012

Accepted 25 July 2012

Available online 2 August 2012

\section{Keywords:}

CA inhibitors

CA I isoform

Carboxylic acids/carboxylates

Metal complexes

5-(1-Alyl-1H-indol-3-yl)-1H-pyrazole-3carboxylic acids

(Z)-Methyl 2-hydroxy-2-(2-oxo-1-

substituted-indolin-3-ylidene)acetates

\begin{abstract}
A B S T R A C T
The members of a focused series of carboxylic acids and of their derivatives (esters, amides and metal complexes) have been investigated as inhibitors of the main cytosolic/transmembrane carbonic anhydrase isoforms, CA I, II, IX and XII, belonging to the mammalian $\alpha$-class of CAs. These enzymes are present in red blood cells in submillimolar concentration, and typical sulfonamide CA inhibitors do not selectively inhibit any of them. Among such isozymes, the isoform-I is an 'orphan' target that mediates hemorrhagic retinal and cerebral vascular permeability, involved in retinal and cerebral disease. In the present study, we identified the first selective CA I nanomolar inhibitors, that displayed activity against other isozymes in micromolar/millimolar concentration range. Selective CA II over CA I inhibition has also been observed with some diketo acids/metal complexes. Few diketo acid derivatives showed inhibition activities against the fungal $\beta$-class enzymes from Candida albicans and Cryptococcus neoformans in low micromolar concentration range. Prediction of drug-like properties for the most interesting compounds suggests a favorable bioavailability.
\end{abstract}

(c) 2012 Elsevier Ltd. All rights reserved.
Carbonic anhydrases (CAs, EC 4.2.1.1), as isoforms I and II, are highly abundant in red blood cells (and in gastrointestinal tract) of vertebrates, arriving at concentrations as high as $0.2 \mathrm{mM}$, and having an important role in $\mathrm{CO}_{2}$ transport to the lungs, and in blood pH homeostasis. ${ }^{1,2}$ These two cytosolic isoforms are the dominant ones among the 16 CAs found to date in various cell/tissues in vertebrates. ${ }^{3-7}$ This family of metalloproteins uses $\mathrm{Zn}^{2+}$ as metal cofactor and catalyzes the simple reaction between carbon dioxide and water with generation of bicarbonate and protons: $\mathrm{CO}_{2}+\mathrm{H}_{2} \mathrm{O}=\mathrm{H}^{+}+\mathrm{HCO}_{3}{ }^{-3-6}$ In humans, in addition to blood, CAs are present in a large variety of tissues including gastrointestinal and reproductive tracts, central nervous system, kidneys, lungs, skin and eyes. ${ }^{3-6}$ The different isozymes are localized in various cellular compartments with CA I, CA II, CA III, CA VII and CA XIII being found in the cytosol, two isoforms (CA VA and $\mathrm{VB}$ ) are present in mitochondria and one isoform (CA VI) is secreted in saliva and milk. Several other CA isoforms are either associated through

\footnotetext{
* Corresponding authors. Tel.: +39 079228 753; fax: +39 079228745 (M.S.); tel.: +39055 4573005; fax: +39055 4573385 (C.T.S.).

E-mail addresses: mario.sechi@uniss.it (M. Sechi), claudiu.supuran@unifi.it (C.T. Supuran).
}

phosphoinositol glycan anchors to the plasma membranes (CA IV and $\mathrm{XV}$ ) or they are transmembrane proteins with extracellular active sites (CA IX, XII and XIV). ${ }^{3-7}$ Many of the CA isozymes are important therapeutic targets, and are involved in several physiological/pathological processes, with the potential to be inhibited/ activated for treating a large range of disorders. ${ }^{3-10}$ For example, CA II plays a role in bicarbonate production in the eye and it is therefore a validated target for the therapy of glaucoma. ${ }^{3,4}$ CA IX and CA XII are extracellularly localized mainly on hypoxic tumor cells, ${ }^{8-10}$ where they are involved in tumorigenesis by regulating $\mathrm{pH}$ inside and outside the cancer cell, ${ }^{5}$ thus interfering with phosphorylation processes or by playing a role in the cell-cell adhesion. ${ }^{5,10}$ Therefore, they provide a target for cancer therapy because of their specificity towards the hypoxic tumor cells. Concerning the isozyme CA I, that is considered an 'orphan' target, it has been shown that the presence of extracellular CA I inside either the blood-retinal or blood-brain barrier can induce vasogenic edema. ${ }^{11}$ Increased retinal vascular permeability contributes to the pathogenesis of proliferative diabetic retinopathy and diabetic macular edema, leading causes of vision loss in working-age adults. Elevated levels of extracellular CA I in vitreous from individuals with diabetic retinopathy suggest that retinal hemorrhage and erythrocyte lysis contribute to 
the diabetic vitreous proteome. Alkalinization of vitreous induced by CA I affects some biological activities, such as kallikrein activity and its generation of factor XIIa, revealing a new pathway for contact system activation. Thus, the release of erythrocyte CA I may account for the increased vascular permeability and edema in diabetic retinopathy or following subdural hematoma. Therefore, inhibition of extracellular CA I is a major challenge, and could provide new therapeutic opportunities for the treatment of hemorrhage-induced retinal and cerebral edema. ${ }^{11}$

As far as the known CA inhibitors (CAIs) are concerned, the sulfonamides and their isosteres (sulfamates, sulfamides, etc.) have been clinically used for more than 60 years and constitute the most investigated chemical classes of inhibitors. ${ }^{3-5,12}$ However, these compounds indiscriminately inhibit many of the $16 \mathrm{CA}$ isoforms known in mammals. Thus, efforts have been made to find new CAIs, in order: (a) to explore molecular diversities and to discover original pharmacophores, (b) to identify novel inhibitors that selectively inhibit each isoform, and (c) to develop hit/lead compounds able to interfere with CA 'orphan' targets, such as the CA isoform-I. Recently, the inhibitors belonging to the coumarin family were discovered as mechanism-based inhibitors, which act as prodrugs and bind in a very different mode compared to sulfonamides and their isosteres (I, Fig. 1)..$^{13,14}$

The trifluoro-dihydroxy-propanone moiety (II, Fig. 1), discovered using combinated ligand- and pharmacophore-based virtual screening approaches, represents another interesting bioisosteric alternative to the sulfonamido-based functionalities. ${ }^{15}$ Some polyamines (such as spermine and its derivatives, III), ${ }^{16}$ as well as a range of natural product phenols/carboxylic acids (IV), ${ }^{17,18}$ were also investigated (Fig. 1), and showed interesting properties and novel putative mechanisms of inhibition.

In this context, carboxylate-based compounds represent interesting chemotypes for CA inhibition, as the $\mathrm{COO}^{-}$is an effective zinc-binding group in many zinc enzymes, but it is less investigated for the CAs. Previously, a series of aromatic and aliphatic carboxylates (V, Fig. 1) were evaluated for the inhibition of both mammalian $\alpha$-class CA isoforms (CA I, II, IX and XII $)^{19}$ and $\beta$-CAs from pathogenic fungi and bacteria. ${ }^{20}$ Among various CA isoforms, only hCA IV resulted sensitive to several carboxylate derivatives, whereas other ones (i.e. hCA II, V, and IX) were not inhibited by such compounds.

Considering that carboxylic acids and several of their derivatives are chemically accessible, thus offering a wide and unexplored chemical space for designing enzyme inhibitors, we selected a series of carboxylic/carboxylates based compounds to be submitted to an extensive biological screening.

First, an in-house library of $\sim 150$ compounds was built by choosing structural backbones carrying such carboxylic/carboxylate functionalities (Fig. 2, stages 1 and 2), and having potential as CAIs on the base of their previously evaluated chelating ability towards metal cofactors of other metalloenzymes. ${ }^{21-25}$ Then, after a preliminary screening against CA I/CA II isozymes (data not presented), the most interesting compounds 1-18 were selected ( Fig. 2, stage 3, and Fig. 3) and submitted to further investigation.

Most of the studied compounds were previously reported (1-3, $\mathbf{5}, \mathbf{6}, \mathbf{9 - 1 8}) ;{ }^{21-25} \mathbf{4}$ was commercially available, ${ }^{26}$ whereas $\mathbf{7}$ and $\mathbf{8}$ have been newly obtained. Briefly, the (alkyl)indol-yl-pyrazole-3carboxylic acids $\mathbf{7}$ and $\mathbf{8 a}$ were obtained by treating under alkaline conditions the respective esters $\mathbf{2 1}$ and $\mathbf{8 b}$, which were synthesized by cyclocondensation of $\beta$-diketoesters 20a,b with hydrazine hydrate (Scheme 1). ${ }^{27}$

These intermediates were easily prepared by oxalylation of the corresponding ketones 19a,b in the presence of sodium methoxide in methanol under reflux conditions. 19a and 19b were synthesized following a reported procedure. ${ }^{21,24}$

Compounds 1-18 were tested for the ability to inhibit CA I, II, IX and XII $\alpha$-isoforms and $\beta$-CAs Nce103 and Can 2 catalytic activities, obtained by a stopped-flow technique as previously described. ${ }^{28,29}$<smiles>[R]c1c([R])c([R])c2oc(=O)ccc2c1[R]</smiles><smiles>COc1cc2oc(=O)ccc2cc1C(O)CC(C)C</smiles>

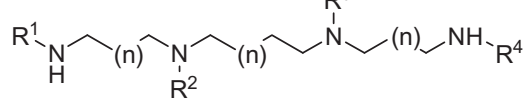<smiles>O=C(O)c1cc(O)c(O)c(O)c1</smiles><smiles>O=C1OC2=C(O)C(O)=CC3C(=O)Oc4c(O)c(O)cc1c4C23</smiles><smiles>COc1cc(C)cc2oc3ccc(O)c(C(=O)O)c3c(=O)c12</smiles><smiles>CC(=O)CC(=O)O</smiles><smiles>CC(O)CC(=O)O</smiles><smiles>[R]CNC(=O)Cc1ccc(O)c(Cl)c1</smiles><smiles>O=C(O)CC(O)(CC(=O)O)C(=O)O</smiles><smiles>CC(C)c1c(C(=O)Nc2ccccc2)c(-c2ccccc2)c(-c2ccc(F)cc2)n1CCC(O)CC(O)CC(=O)O</smiles><smiles>Cc1c(/C=C/C(O)CC(O)CC(=O)O)n(C(C)C)c2ccccc12</smiles><smiles>O=C(O)CN(CC(=O)O)Cc1ccccc1</smiles><smiles>O=C1CN(Cc2ccccc2)CC(=O)N1O</smiles>

Figure 1. Representative structures of nonsulfonamide-containing CAIs. 


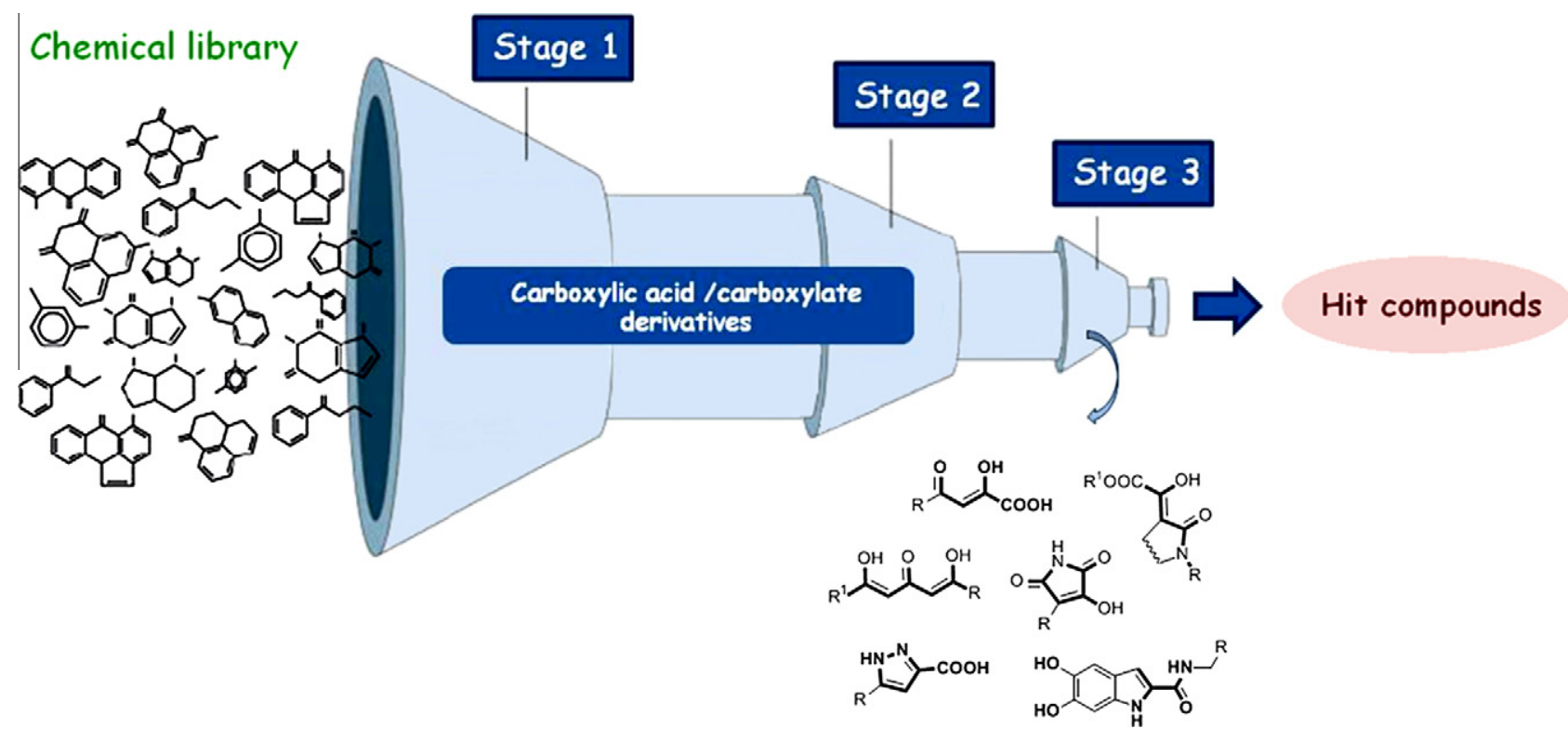

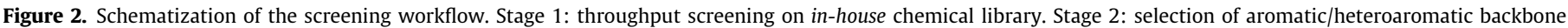
with carboxylic acid/carboxylate-based functionalities. Stage 3: intensive inhibition study and identification of hit compounds.

In general, almost all tested compounds showed inhibitory activity in nanomolar/micromolar range, as reported in Table 1. In particular, the $\beta$-diketo acids $\mathbf{1}, \mathbf{2 a}, \mathbf{3}$, and the $\beta$-diketo ester 2b shared a similar CA inhibitory profile across all isoforms, with quite selectivity of $\mathbf{1}$ and $\mathbf{2 a}$ for the $\beta$-form Can $2\left(K_{\mathrm{I}}=0.89 \mu \mathrm{M}\right)$. The fumaric acid derivative 4 displayed an interesting inhibition potency against CA II in nanomolar concentration $\left(K_{\mathrm{I}}=0.045 \mu \mathrm{M}\right)$, as already evidenced for some related compounds. ${ }^{19}$ The triketobased compound 6a exhibited a certain selectivity for hCAs IX and XII $\left(K_{\mathrm{I}} \mathrm{S}=0.72\right.$ and $0.77 \mu \mathrm{M}$, respectively), in line with those of other related derivatives. ${ }^{20}$ Importantly, the 5-(1-ethyl-1H-indol-3-yl)-1H-pyrazole-3-carboxylic acid (7) proved to be the most potent and selective compound tested toward CA I isoform $\left(K_{\mathrm{I}} \mathrm{S}=0.042 \mu \mathrm{M}\right)$, with a very high CA I versus CA II selectivity $\left(K_{\mathrm{I}}=1829 \mu \mathrm{M}\right.$ for CA II, SI, selectivity index $\left.=>40,000\right)$, without it significantly affects the catalytic activities of the other isozymes. The $N$-benzyl ester and acid homologues $\mathbf{8 a}$ and $\mathbf{8 b}$ did not show significant inhibition profiles versus CA I: when a substitution of the ethyl with a benzyl occurs, the difference in size and shape can play, together with the hydrophobic properties, an important role in the CA inhibitory activity for this set of compounds. Again, interesting CA I nanomolar inhibition and selectivity (SI for CA I vs CA II $=\sim 85$ and $\sim 27$, for $\mathbf{1 0 b}$ and $\mathbf{1 0 a}$, respectively) have been shown by compounds bearing a hydroxy-oxoindolin-ylidene carboxylate pharmacophore. The $N$-phenyl ester $\mathbf{1 0 b}$ resulted about 20-fold more active than the unsubstituted one 10a (CA I $K_{\mathrm{I}} \mathrm{S}=0.049$ vs $1.05 \mu \mathrm{M}$, for $\mathbf{1 0 b}$ and 10a, respectively). The addition of a phenyl group on the oxoindole ring significantly enhances the potency, while the replacement of the ester with a carboxylic acid functionality dramatically leads to a decrease in CA I inhibitory activity (CA II $K_{\mathrm{I}}=38.0 \mu \mathrm{M}$, for 9). Moreover, the 3-hydroxy-1Hpyrrole-2,5-dione derivative $\mathbf{1 1}$ demonstrated a selective inhibition for CA II in low micromolar concentration (CA II $K_{\mathrm{I}}=0.63 \mu \mathrm{M}$ ), whereas the inhibition potency against the other enzymes ranged from 6.65 to 8.75 micromolar concentration. Finally, a selective nanomolar inhibition for CA II isozyme has been detected for the diketo acid-metal complexes $\mathbf{1 5}$ and $\mathbf{1 7}$ with $\mathrm{Mn}$ (II) (CA II $K_{\mathrm{I}}=0.042 \mu \mathrm{M}$ ) and $\mathrm{Zn}(\mathrm{II})$ (CA II $K_{\mathrm{I}}=0.043 \mu \mathrm{M}$ ), respectively, whereas the complexes $\mathbf{1 6}$ and $\mathbf{1 8}$ as well as the mononuclear $\mathrm{Mg}(\mathrm{II})$-complex 14 resulted less potent of about one/two orders of magnitude. It is interesting to note that coordination of metal ions by $\beta$-diketo acid $\mathbf{1}$ or $\mathbf{2 a}$ to form a bimetallic complex led to an increase in potency against CA II and to a loss in activity versus $\beta$-Can2 enzyme.

Among the tested compounds, the most potent CA I inhibitors (i.e. the heteroaryl-pyrazole carboxylic acid $\mathbf{7}$ and the hydroxyoxoindolin-ylidene carboxylate $\mathbf{1 0 b}$ ) could interact with the $\mathrm{Zn}(\mathrm{II})$ ion involving their carboxylate functionalities, similarly to sulfonamides and related inhibitors, as revealed by X-ray in co-crystals of hCA II with other carboxylates. ${ }^{18}$ However, such molecules bear other atoms/groups that may participate to the inhibition mechanism. In particular, 7 presents two nitrogen atoms in the pyrazole ring, which can modulate the interaction with the zinc ions and/or with the amino acid pattern within the enzyme active site. In this direction, also compound 10b, with additional hydroxy and oxo functionalities, can share a favorable binding motif for selective anti-CA I activity. Introduction of additional groups in a particular orientation with respect to the carboxylate function appears a suitable strategy to enhance the carboxylates binding ability.

The difference in activities showed by $\mathbf{7}$ and by the other members of the pyrazole carboxylic acid class ( $\mathbf{8 a}$ and $\mathbf{8 b}$ ) can be explained by considering that at the end of their indolic backbone is placed an aromatic bulky group, that can give unfavorable interactions and/or steric hindrance between the aryl/heterocyclic backbone and the amino acid residues at the entrance of the cavity of the active site. Since this part of the protein CA I is the most variable one among the different CA isoforms, specific structural determinants and favorable combination of physicochemical features, in term of electronic and steric properties, are required. However, more studies are needed to carefully investigate the mechanism of action. The possibility that such inhibitors would behave differently, for example by establishing different putative binding modes, should be also considered.

Since the valuation of pharmacokinetic, pharmacodynamic and toxicity is also essential to address to a successful drug discovery process and to predict the therapeutic potential of a drug candidate, ${ }^{30-32}$ calculation of selective physicochemical properties important for absorption, distribution, metabolism, excretion, and toxicity (ADME-Tox) for the most interesting CA I inhibitors 7 and 10b was performed. In this context, Lipinski's rule-of-five 
<smiles>O=C([O-])C(O)=CC(=O)c1ccccc1</smiles><smiles>[R]OC(=O)C(O)=CC(=O)c1cccn1Cc1ccc(F)cc1</smiles><smiles>O=C(O)/C(O)=C/C(=O)c1cn(Cc2ccccc2)c2ccccc12</smiles><smiles>CC(=O)c1c(C(=O)O)n(C)c2cc3c(cc12)OCO3</smiles><smiles>[R]OC(=O)/C(O)=C/C(=O)/C=C(\O)c1ccccc1OC</smiles><smiles>CCn1cc(-c2cc(C(=O)O)n[nH]2)c2ccccc21</smiles><smiles>[R]OC(=O)c1cc(-c2cn(Cc3ccccc3)c3ccccc23)[nH]n1</smiles><smiles>O=C(O)/C(O)=C1\C(=O)Nc2ccccc21</smiles><smiles>[R]N1C(=O)C(=C(O)C(=O)O)c2ccccc21</smiles>

10 a: $\mathrm{R}=\mathrm{H}$<smiles>CCn1cc(C2=C(O)C(=O)NC2=O)c2ccccc21</smiles><smiles>O=C(NCCc1ccc(O)c(O)c1)c1cc2cc(O)c(O)cc2[nH]1</smiles><smiles>COC(=O)C1=CC(c2ccccc2)=CC(=C(O)C(=O)OC)O1</smiles>

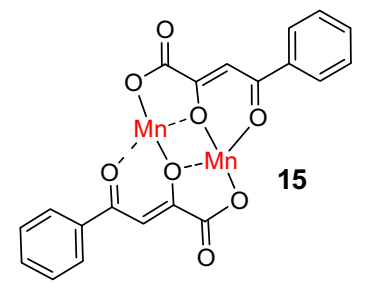

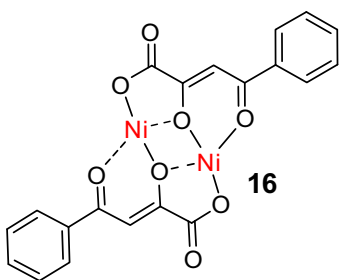

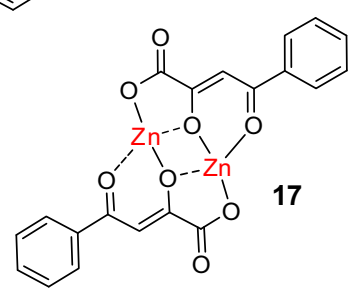

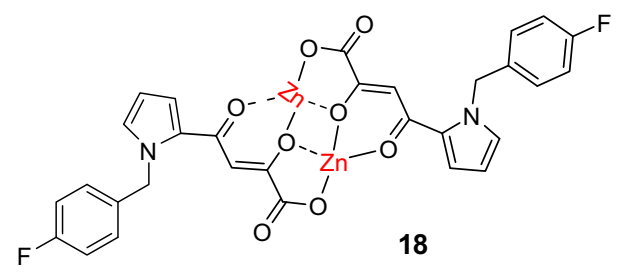

Figure 3. Compounds selected in this study

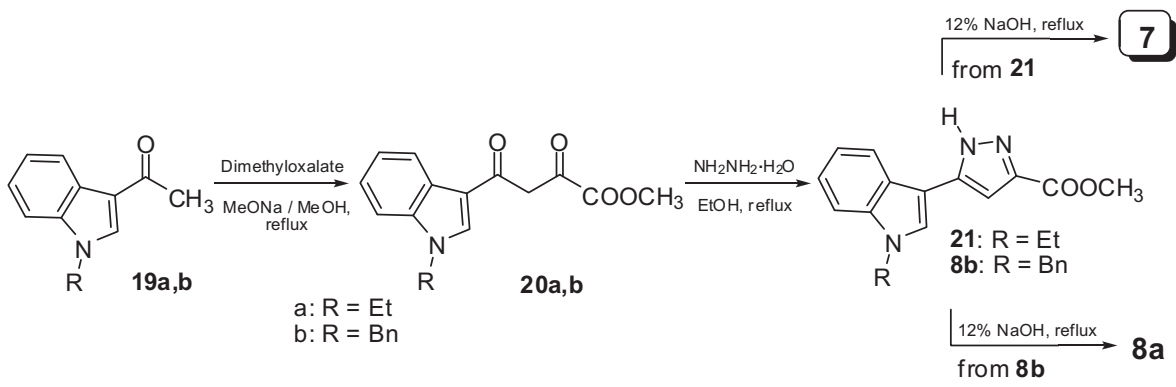

Scheme 1. Synthetic route for the preparation of compounds $\mathbf{7}$ and $\mathbf{8}$.

(i.e. compounds are considered likely to be well absorbed when they possess $c \log P<5$, molecular weight $<500$, number $\mathrm{H}$-bond acceptors $<10$, and number of $\mathrm{H}$-bond donors $<5)^{33}$ is a simplified method to predict the solubility and the membrane permeability of a small molecule. Further studies suggest that compounds with polar surface area (PSA) $<60 \AA$ will likely have good absorption ( $>90 \%$ ), whereas other ones with PSA $>140 \AA$ are predicted to be poorly absorbed $(<10 \%){ }^{34-36}$ As shown in Table 2 , the calculated atom-based values (i.e. molecular weight, $\mathrm{H}$-bond acceptor and donor counts, the $c \log P, \operatorname{miL} \operatorname{Lg} P$ and TPSA $)^{37}$ for both compounds fall 
Table 1

Human CA I, II, IX and XII, and $\beta$-CAs (Nce103 and Can2) from pathogenic fungi and bacteria inhibition data for compounds 1-18 by a stopped flow $\mathrm{CO}_{2}$ hydrase assay at $\mathrm{pH} 7.5$ and $20^{\circ} \mathrm{C}$. The sulfonamide inhibitors AAZ and DCP were also included as standards

\begin{tabular}{lllccll}
\hline \multirow{2}{*}{ Compound } & \multicolumn{5}{c}{$\mathrm{K}_{\mathrm{I}}(\mu \mathrm{M})^{\mathrm{a}}$} \\
\cline { 2 - 7 } & hCA I & hCA II & hCA IX & hCA XII & Nce 103 & Can2 \\
\hline $\mathbf{1}$ & 3.35 & 4.30 & 6.79 & 7.75 & 8.76 & 0.89 \\
$\mathbf{2 a}$ & 5.07 & 2.65 & 6.93 & 7.94 & 9.27 & 0.94 \\
$\mathbf{2 b}$ & 5.53 & 3.27 & 6.86 & 8.51 & 9.39 & 9.73 \\
$\mathbf{3}$ & 2.78 & 1.93 & 8.28 & 7.64 & 8.81 & 9.63 \\
$\mathbf{4}$ & 4.41 & 0.045 & 6.70 & 7.15 & 8.28 & 10.2 \\
$\mathbf{5}$ & 7.50 & 5.20 & 16.7 & 13.9 & 12.3 & 16.3 \\
$\mathbf{6 a}$ & 4.02 & 4.35 & 0.72 & 0.77 & 8.45 & 10.4 \\
$\mathbf{6 b}$ & 1.20 & 4.55 & 7.57 & 7.05 & 8.36 & 9.85 \\
$\mathbf{7}$ & 0.042 & 1820 & 7.79 & 7.78 & 8.94 & 9.69 \\
$\mathbf{8 a}$ & 6.20 & 3.62 & 6.12 & 3.24 & 8.47 & 10.4 \\
$\mathbf{8 b}$ & 1.65 & 1.19 & 9.24 & 12.8 & 15.6 & 15.8 \\
$\mathbf{9}$ & 38.0 & 4.36 & 7.68 & 0.48 & 7.62 & 9.33 \\
$\mathbf{1 0 a}$ & 1.05 & 28.5 & 8.02 & 6.96 & 7.75 & 10.4 \\
$\mathbf{1 0 b}$ & 0.049 & 4.14 & 8.05 & 5.03 & 8.44 & 10.1 \\
$\mathbf{1 1}$ & 7.53 & 0.63 & 6.65 & 8.66 & 8.40 & 8.75 \\
$\mathbf{1 2}$ & 3.60 & 1.45 & 16.23 & 14.3 & $>20$ & $>20$ \\
$\mathbf{1 3}$ & 1.85 & 3.02 & 15.10 & 9.24 & $>20$ & $>20$ \\
$\mathbf{1 4}$ & 4.15 & 2.60 & 9.23 & 6.38 & 18.5 & $>20$ \\
$\mathbf{1 5}$ & 4.59 & 0.042 & 9.14 & 7.26 & 12.2 & $>20$ \\
$\mathbf{1 6}$ & 4.34 & 0.70 & 8.73 & 6.19 & 13.6 & $>20$ \\
$\mathbf{1 7}$ & 2.73 & 0.043 & 8.70 & 8.29 & 11.7 & $>20$ \\
$\mathbf{1 8}$ & 3.40 & 0.85 & 10.24 & 8.04 & 15.9 & $>20$ \\
AAZ & 0.25 & 0.012 & 0.025 & 0.006 & 0.132 & 0.010 \\
DCP & 1.20 & 0.038 & 0.050 & 0.050 & 1.07 & 0.087 \\
\hline $\mathbf{a}$ & & & & & \\
\hline
\end{tabular}

${ }^{a}$ Mean from 3 different assays. Errors were in the range $\pm 5-10 \%$ of the reported values (data not shown). $\mathrm{AAZ}=$ acetazolamine; $\mathrm{DPC}=$ diphenylamine-2-carboxylic acid.

within the desirable range for good absorption and membrane permeability, therefore suggesting a favorable bioavailability. The selected compounds are predicted to have desirable drug-like properties, thus making them suitable for further optimization and experimental evaluations.

In conclusion, to identify novel pharmacophores required for anti-CA activity, a series of carboxylic acids and their derivatives, with various molecular diversities, have been investigated as inhibitors of the $\alpha$-class of CA I, II, IX and XII isoforms, and of the fungal $\beta$-class enzymes from Candida albicans and Cryptococcus neoformans. Since CAIs with peculiar selectivity for each isozyme are of paramount importance, we made a major effort in identifying novel CAIs differing from the well-known sulfonamide, sulfamate and sulfamides, endowed with selectivity against relatively unexplored targets, such as CA I. This isoform is involved in retinal and cerebral disease, and we pursued the hypothesis that proteins downstream of CA I could represent therapeutic targets for inhibiting CA I-induced vascular permeability. The present study reports on the first prototype of CAIs targeting the CA-I isoform, carrying an original pharmacophore able to selectively interfere with such isozyme in nanomolar concentration range. Moreover,

Table 2

Physicochemical properties of selected compounds $\mathbf{7}$ and $\mathbf{1 0 b}$

\begin{tabular}{llllllll}
\hline Compound & MW & HBA & HBD & Rbond & $c \log P^{\mathrm{a}}$ & $\operatorname{miLog} P^{\mathrm{b}}$ & TPSA $^{\mathrm{c}}$ \\
\hline $\mathbf{7}$ & 255.3 & 4 & 2 & 3 & 3.65 & 2.397 & 70.916 \\
$\mathbf{1 0 b}$ & 295.3 & 3 & 1 & 3 & 2.12 & 2.167 & 68.538
\end{tabular}

Abbreviations: MW, molecular weight; HBA, number of hydrogen bond acceptors; HBD, number of hydrogen bond donors; Rbond, number of rotatable bonds; $c \log P$, $\log$ octanol-water partition coefficient; $\operatorname{miL} \log P, \log P$ prediction based on group contributions; TPSA, topological polar surface area.

a Parameters calculated by ChemDraw Ultra 2005

b Parameters calculated by miLog $P 2.2$ method implemented in Molinspiration Cheminformatics 2012 software.

c Parameters calculated by Molinspiration Cheminformatics 2012. we observed a selective CA II over CA I inhibition by some tested metal complexes, as well as a certain inhibition activity of the fungal $\beta$-class enzymes from Candida albicans and Cryptococcus neoformans by few diketo acid derivatives. Interestingly, computational simulations suggested that the most interesting compounds $\mathbf{7}$ and 10b can meet desirable ADME criteria and favorable pharmacokinetic properties for further development. In addition, due to its selectivity index between CA I/CA II $(S I=>40,000)$, compound 7 shows a potential therapeutic window.

We highlighted that the discovered heteroaryl-pyrazole carboxylic acids and the hydroxy-oxoindolin-ylidene carboxylates can represent novel promising lead compounds for the development of potent and selective CA I inhibitors, and as such further preclinical studies, also devoted to elucidate their inhibition mechanism, are warranted.

\section{Acknowledgements}

M.S. is grateful to Fondazione Banco di Sardegna for its partial financial support. The work in CS's group was supported by Metoxia (European $7^{\text {th }}$ framework programme).

\section{References and Notes}

1. Dodgson, S. J.; Foster, R. E., II J. Appl. Physiol. Respir. Environ. Exerc. Physiol. 1983, 55, 1292.

2. Ridderstråle, Y.; Fierke, C. A.; Roush, E. D.; Wistrand, P. J. Acta Physiol. Scand. 2002, 176, 27.

3. Supuran, C. T. Nat. Rev. Drug Disc. 2008, 7, 168.

4. (a) Supuran, C. T. Bioorg. Med. Chem. Lett. 2010, 20, 3467; (b) Pastorekova, S.; Parkkila, S.; Pastorek, J.; Supuran, C. T. J. Enzyme Inhib. Med. Chem. 2004, 19, 199.

5. Neri, D.; Supuran, C. T. Nat. Rev. Drug Disc. 2011, 10, 767.

6. Supuran, C. T.; Scozzafava, A.; Casini, A. Med. Res. Rev. 2003, 23, 146.

7. Aspatwar, A.; Tolvanen, M. E.; Parkkila, S. BMC Mol. Biol. 2010, 11, 25.

8. Alterio, V.; Hilvo, M.; Di Fiore, A.; Supuran, C. T.; Pan, P.; Parkkila, S.; Scaloni, A.; Pastorek, J.; Pastorekova, S.; Pedone, C.; Scozzafava, A.; Monti, S. M.; De Simone, G. Proc. Natl. Acad. Sci. U.S.A. 2009, 106, 16233.

9. Lou, Y.; McDonald, P. C.; Oloumi, A.; Chia, S. K.; Ostlund, C.; Ahmadi, A.; Kyle, A. Auf dem Keller, U.; Leung, S.; Huntsman, D. G.; Clarke, B.; Sutherland, B. W.; Waterhouse, D.; Bally, M. B.; Roskelley, C. D.; Overall, C. M.; Minchinton, A.; Pacchiano, F.; Carta, F.; Scozzafava, A.; Touisni, N.; Winum, J. Y.; Supuran, C. T.; Dedhar, S. Cancer Res. 2011, 71, 3364.

10. Ditte, P.; Dequiedt, F.; Svastova, E.; Hulikova, A.; Ohradanova-Repic, A.; Zatovicova, M.; Csaderova, L.; Kopacek, J.; Supuran, C. T.; Pastorekova, S.; Pastorek, J. J. Cancer Res. 2011, 71, 7558.

11. Gao, B. B.; Clermont, A.; Rook, S.; Fonda, S. J.; Srinivasan, V. J.; Wojtkowski, M.; Fujimoto, J. G.; Avery, R. L.; Arrigg, P. G.; Bursell, S. E.; Aiello, L. P.; Feener, E. P. Nature Med. 2007, 13, 181.

12. (a) Supuran, C. T. Curr. Pharm. Des. 2008, 14, 641; (b) De Simone, G.; Di Fiore, A.; Supuran, C. T. Curr. Pharm. Des. 2008, 14, 655.

13. Maresca, A.; Temperini, C.; Vu, H.; Pham, N. B.; Poulsen, S. A.; Scozzafava, A.; Quinn, R. J.; Supuran, C. T. J. Am. Chem. Soc. 2009, 131, 3057.

14. Carta, F.; Temperini, C.; Innocenti, A.; Scozzafava, A.; Kaila, K.; Supuran, C. T. J. Med. Chem. 2010, 53, 5511.

15. Pala, N.; Dallocchio, R.; Dessì, A.; Brancale, A. Carta, F.; Ihm, S.; Maresca, A. Sechi, M.; Supuran, C. T. Bioorg. Med. Chem. Lett. 2011, 21, 2515.

16. Innocenti, A.; Vullo, D.; Scozzafava, A.; Supuran, C. T. Bioorg. Med. Chem. Lett. 2008, 18, 1583.

17. Davis, R. A.; Hofmann, A.; Osman, A.; Hall, R. A.; Mühlschlegel, F. A.; Vullo, D.; Innocenti, A.; Supuran, C. T.; Poulsen, S. A. J. Med. Chem. 2011, 54, 1682.

18. De Simone, G.; Supuran, C. T. J. Inorg. Biochem. 2012, 111, 117.

19. (a) Innocenti, A.; Vullo, D.; Scozzafava, A.; Casey, J. R.; Supuran, C. T. Bioorg Med. Chem. Lett. 2005, 15, 573; (b) Santos, M. A.; Marques, S.; Vullo, D.; Innocenti, A.; Scozzafava, A.; Supuran, C. T. Bioorg. Med. Chem. Lett. 2007, 17, 1538.

20. (a) Innocenti, A.; Hall, R. A.; Schlicker, C.; Mühlschlegel, F. A.; Supuran, C. T. Bioorg. Med. Chem. 2009, 17, 2654; (b) Carta, F.; Innocenti, A.; Hall, R. A.; Mühlschlegel, F. A.; Scozzafava, A.; Supuran, C. T. Bioorg. Med. Chem. Lett. 2011, 21, 2521; (c) Parkkila, S.; Vullo, D.; Maresca, A.; Carta, F.; Scozzafava, A.; Supuran, C. T. Chem. Commun. 2012, 48, 3551.

21. Sechi, M.; Derudas, M.; Dallocchio, R.; Dessì, A.; Bacchi, A.; Sannia, L.; Carta, F.; Palomba, M.; Ragab, O.; Chan, C.; Shoemaker, R.; Sei, S.; Dayam, R.; Neamati, N. J. Med. Chem. 2004, 47, 5298.

22. Sechi, M.; Angotzi, G.; Dallocchio, R.; Dessì, A.; Carta, F.; Sannia, L.; Mariani, A.; Fiori, S.; Sanchez, T.; Movsessian, L.; Plasencia, C.; Neamati, N. Antiviral Chem. Chemother. 2004, 15, 67.

23. Sechi, M.; Sannia, L.; Carta, F.; Palomba, M.; Dallocchio, R.; Dessì, A.; Derudas, M.; Zawahir, Z.; Neamati, N. Antiviral Chem. Chemother. 2005, 16, 41 
24. Sechi, M.; Sannia, L.; Orecchioni, M.; Carta, F.; Paglietti, G.; Neamati, N. J. Heterocycl. Chem. 2003, 40, 1097.

25. Sechi, M.; Bacchi, A.; Carcelli, M.; Compari, C.; Duce, E.; Fisicaro, E.; Rogolino, D.; Gates, P.; Derudas, M.; Al-Mawsawi, L. Q.; Neamati, N. J. Med. Chem. 2006, 49, 4248 .

26. Provided from Sigma-Aldrich. CAS Number: 199926-38-0; PubChem Substance ID 24893359.

27. General procedure for the preparation of the esters $\mathbf{2 1}$ and $\mathbf{8 b}$. For general experimental information see in Ref. 24 A solution of the methyl 2,4-dioxo-4phenylbutanoates $(\mathbf{2 0 a}, \mathbf{b})^{21}(4.85 \mathrm{mmol})$ and hydrazine hydrochloride ( 3 mole equiv) in ethanol $(20 \mathrm{~mL}$ ) was refluxed for 5 (for $\mathbf{2 1}$ ) or 7 (for $\mathbf{8 b}$ ) hours. After evaporation in vacuo a pale yellow solid was obtained that was purified by silica flash chromathography (hexane/ethyl acetate $=8: 2$ ). The product was recrystallized from water-ethanol to give $\mathbf{2 1}$ and $\mathbf{8 b}$ as yellow crystals. Methyl 5-(1-ethyl-1H-indol-3-yl)-1H-pyrazole-3-carboxylate (21). Yield: 57\%, mp 174-175 ${ }^{\circ} \mathrm{C}$; IR (Nujol): 1730 (C=0, ester) $\mathrm{cm}^{-1} ;{ }^{1} \mathrm{H}$ NMR $\left(\mathrm{CDCl}_{3}\right): \delta$ 7.9-8.0 (m, 1H, ArH), 7.48 (s, 1H, NH), 7.20-7.40 (m, 4H, ArH), 7.08 (s, 1H, ArH), $4.22\left(\mathrm{q}, 2 \mathrm{H}, \mathrm{CH}_{2}\right), 3.95\left(\mathrm{~s}, 3 \mathrm{H}, \mathrm{CH}_{3}\right), 1.55\left(\mathrm{t}, 3 \mathrm{H}, \mathrm{CH}_{3}\right) ; \mathrm{GC} / \mathrm{MS}: \mathrm{m} / z 269(\mathrm{M}+)$. Methyl 5-(1-benzyl-1H-indol-3-yl)-1H-pyrazole-3-carboxylate (8b). Yield: 65\%, mp 221-222 ${ }^{\circ} \mathrm{C}$; IR (Nujol): $1720\left(\mathrm{C}=0\right.$, ester) $\mathrm{cm}^{-1} ;{ }^{1} \mathrm{H}$ NMR $(\mathrm{CDCl} 3): \delta 7.90-$ $8.00(\mathrm{~m}, 1 \mathrm{H}, \mathrm{ArH}), 7.74(\mathrm{~s}, 1 \mathrm{H}, \mathrm{NH}), 7.54(\mathrm{~s}, 2 \mathrm{H}, \mathrm{ArH}), 7.15-7.40(\mathrm{~m}, 7 \mathrm{H}, \mathrm{ArH})$, 7.07 (s, 1H, ArH), 5.38 (s, 2H, $\left.\mathrm{CH}_{2}\right), 3.93\left(\mathrm{~s}, 3 \mathrm{H}, \mathrm{CH}_{3}\right) ; \mathrm{GC} / \mathrm{MS}: \mathrm{m} / z 331(\mathrm{M}+$ ). General procedure for the preparation of the acids $\mathbf{7}$ and $\mathbf{8 a}$. A solution of the appropriate ester (21 and $\mathbf{8 b})(1.3 \mathrm{mmol}$ ) and $12 \% \mathrm{NaOH}$ pellets (4 equiv) in ethanol $(40 \mathrm{~mL})$ was stirred under reflux for $2 \mathrm{~h}$. Then, water was added and the solution was acidified with $6 \mathrm{~N} \mathrm{HCl}$. A white precipitate was filtered, recrystallized from water/ethanol and collected. 5-(1-ethyl-1H-indol-3-yl)-1H-

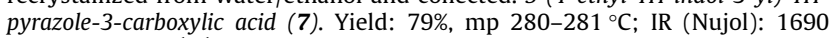
$(\mathrm{C}=\mathrm{O}$, acid $) \mathrm{cm}^{-1} ;{ }^{1} \mathrm{H}$ NMR $\left(\mathrm{CDCl}_{3}\right): \delta 8.00-8.05(\mathrm{~m}, 1 \mathrm{H}, \mathrm{ArH}), 7.60(\mathrm{~s}, 1 \mathrm{H}, \mathrm{NH})$, 7.15-7.45 (m, $4 \mathrm{H}, \mathrm{ArH}), 7.08(\mathrm{~s}, 1 \mathrm{H}, \mathrm{ArH}), 4.22\left(\mathrm{q}, 2 \mathrm{H}, \mathrm{CH}_{2}\right), 2.71(\mathrm{~s}, 1 \mathrm{H}, \mathrm{OH})$ 1.54 (t, 3H, $\left.\mathrm{CH}_{3}\right)$; GC/MS: m/z $255(\mathrm{M}+)$. Acido 5 5-(1-benzyl-1H-indol-3-yl)-1Hpyrazole-3-carboxylic acid (8a). Yield: $67 \%, \mathrm{mp} 234-235^{\circ} \mathrm{C}$; IR (Nujol): 1690 $(\mathrm{C}=0$, acid $) \mathrm{cm}^{-1} ;{ }^{1} \mathrm{H}$ NMR $\left(\mathrm{CDCl}_{3}\right): \delta 7.90-8.05(\mathrm{~m}, 1 \mathrm{H}, \mathrm{ArH}), 7.77(\mathrm{~m}, 2 \mathrm{H}, \operatorname{ArH}$ and 1H, NH), 7.15-7.40 (m, 7H, $\mathrm{ArH}), 7.03(\mathrm{~s}, 1 \mathrm{H}, \mathrm{ArH}), 5.41\left(\mathrm{~s}, 2 \mathrm{H}, \mathrm{CH}_{2}\right), 3.51$ (br s, $1 \mathrm{H}, \mathrm{OH}) ; \mathrm{GC} / \mathrm{MS}: \mathrm{m} / z 317(\mathrm{M}+)$

28. Khalifah, R. G. J. Biol. Chem. 1971, 246, 2561.

29. Enzymatic evaluation. An Applied Photophysics stopped-flow instrument has been used for assaying the CA-catalyzed $\mathrm{CO}_{2}$ hydration activity. ${ }^{29}$ Phenol red (at a concentration of $0.2 \mathrm{mM}$ ) has been used as indicator, working at the absorbance maximum of $557 \mathrm{~nm}$, with 10-20 mM Hepes (pH 7.5) as buffer, and $20 \mathrm{mM} \mathrm{Na}_{2} \mathrm{SO}_{4}$ (for maintaining a constant ionic strength), following the initial rates of the CA-catalyzed $\mathrm{CO} 2$ hydration reaction for a period of 10 $100 \mathrm{~s}$. The $\mathrm{CO}_{2}$ concentrations ranged from 1.7 to $17 \mathrm{mM}$ for the determination of the kinetic parameters and inhibition constants. For each inhibitor, at least six traces of the initial $5-10 \%$ of the reaction have been used for determining the initial velocity. The uncatalyzed rates were determined in the same manner and subtracted from the total observed rates. Stock solutions of inhibitor $(10 \mathrm{mM})$ were prepared in distilled-deionized water, and dilutions up to $0.01 \mathrm{nM}$ were achieved thereafter with distilled-deionized water. Inhibitor and enzyme solutions were preincubated together for $15 \mathrm{~min}$ (data not showed) and for $6 \mathrm{~h}$ at room temperature prior to the assay, to allow formation of the E-I complex. The inhibition constants were obtained by nonlinear least- squares methods using PRISM 3, whereas the kinetic parameters for the uninhibited enzymes from Lineweaver-Burk plots, as reported previously, ${ }^{13}$ represent the means from at least three different determinations.

30. Egan, W. J.; Merz, K. M., Jr; Baldwin, J. J. Med. Chem. 2000, 43, 3867.

31. Egan, W. J.; Lauri, G. Adv. Drug Deliv. Rev. 2002, 54, 273.

32. Clark, D. E.; Grootenhuis, P. D. Curr. Top. Med. Chem. 2003, 3, 1193.

33. Lipinski, C. A.; Lombardo, F.; Dominy, B. W.; Feeney, P. J. Adv. Drug Deliv. Rev. 1997, 23, 3.

34. Palm, K.; Luthman, K.; Ungell, A. L.; Strandlund, G.; Artursson, P. J. Pharm. Sci. 1996, 85, 32.

35. Palm, K.; Stenberg, P.; Luthman, K.; Artursson, P. Pharm. Res. 1997, 14, 568.

36. Palm, K.; Luthman, K.; Ungell, A. L.; Strandlund, G.; Beigi, F.; Lundahl, P.; Artursson, P. J. Med. Chem. 1998, 41, 5382.

37. Ertl, P.; Rohde, B.; Selzer, P. J. Med. Chem. 2000, 43, 3714. 